\title{
IMPACT OF TURKISH MILITARY OPERATIONS ABROAD ON THE FALL OF THE LIRA
}

Arvin Heidernia ${ }^{1}$

\begin{abstract}
In this study, the impact of military operations on the exchange rate is estimated. In particular, this study focuses on military operations in Turkey and its impact on the Turkish lira against the pound sterling. Therefore, the aim of the present study is to investigate the impact of Turkish military operations abroad on the fall of the lira. The purpose of this study is analytical-descriptive and theoretical studies. The results of the present study indicate that Turkey has direct, proxy or tension military operations in Libya, Syria, Iraq, Nagorno-Karabakh and Greek waters, which have a negative effect on the country's relations with the European Union and the United States, leading to a fall in value. The Turkish lira.
\end{abstract}

Keywords: Turkey, military operations, economic crisis, lira value.

\section{INTRODUCTION}

Military tensions are one of the growing global problems and have been the most debated issue in recent years. However, according to the Institute for Economics and Peace (IEP) Global Military Tensions Index (2015) [1], most military operations are mainly concentrated in a small number of countries. Over the past decade, Nigeria, Iraq and Afghanistan have experienced the highest levels of military tension in the world. Nevertheless, countries like Turkey have suffered from military tensions for a long time. In addition, Turkey is exposed to a large number of military operations each year. Historical Statistics The Global Military Tensions Index Report (2014) [2] The Institute for Economics and Peace (IEP) shows that Turkey experiences the highest number of military operations in OECD countries.

\footnotetext{
${ }^{1}$ Department of Humanities and Arts, Zanjan Branch, Islamic Azad University, Zanjan, Iran. E-mail: heidarnia.arvin@gmail.com
} 
GÊNERO E INTERDISCIPLINARIDADE

Economically, most empirical findings in the literature indicate that military operations induce a higher level of uncertainty and negatively affect the economy. There has been an increasing literature on the impact of military tensions on the economy in recent decades, and many of these researchers find the negative impact of military tensions on the economy (Abadie and Gardeazabal, 2003 [3]; Enders and Sandler, 1996 [4]). ; Chen and Siems, 2004 [5]; and Suarez and Pshisva, 2006 [6]).

Given the negative effects of military operations on the economy, in this study we aim to examine the effects of military operations on the exchange rate, especially the Turkish lira against the British pound. The choice of the British pound sterling as the exchange rate reference is due to the amount of investment of British companies based in Turkey. According to the Turkish Foreign Ministry, more than 2,800 British companies trade in Turkey and their total trade volume is about 30 billion Turkish lira. In addition, trade between Turkey and the United Kingdom is about 45 billion Turkish lira, and in addition, British direct investment in 2011 reached 2 billion Turkish lira
$\mathrm{Vol}^{\circ} 02 \mid \mathrm{n}^{\circ} 01$ | ISSN: 2675-7451

https://www.periodicojs.com.br/index.php/gei/inde
(Turkey-UK relations [7]). Given the increasing volume of economic cooperation and relations between Turkey and the United Kingdom, in this study, following the growing concern about terrorist incidents in recent years, we draw attention to the possible negative effects of military operations.

Therefore, the purpose of this study is to provide information to universities, policymakers and business by identifying the relationship between military operations and the foreign exchange market, especially the Turkish lira. In addition, this article helps policymakers and businesses identify the short- and long-term effects of military operations abroad on the exchange rate. In fact, policymakers and businesses can use the findings as input to intervention policy and business strategy, respectively.

\section{LITERATURE REVIEW}

Determining exchange rate fluctuations is a vital issue in macroeconomics and the foreign exchange market. However, forecasting exchange rates remains a challenging task for both academics and foreign exchange traders. In addition, empirical 
GÉNERO E INTERDISCIPLINARIDADE
$\mathrm{Vol}^{\circ} 02\left|\mathrm{n}^{\mathrm{o}} 01\right|$ ISSN: 2675-7451

https://www.periodicojs.com.br/index.php/gei/inde findings from several exchange rate forecasting models, regardless of whether the models are based on advanced statistical framework and macroeconomic fundamentals, can not produce reliable results. For example, the main paper (Meese and Rogoff, 1983 [8]) shows that the structural exchange rate models applied in their paper deviate from the random walking model in the short and long run. Similarly, Musa, 1979 [9] found that exchange rate changes are unexpected and follow a random walk. In subsequent articles (Meese and Rose, 1991 [10]) using nonlinear and non-parametric exchange rate models achieved negative results. Similarly, Engel, 1994 [11] found that Markov switching models only outperform the random walk model if estimated in the sample, whereas random walking is better than the Markov switching model when estimating fit outside the sample. .

According to (Sarno and Tylor, 2002 [12]), by accepting the theory of exchange rate determination of conceivable models, the experimental results on the exchange rate are still not a strong, statistically sufficient and reliable model. Significantly, despite exchange rate models that sometimes produce valid results in the sample, they often do not perform non-sample random walk predictions. Similarly, (Bakta and Van Winkop, 2006 [13]) poor performance of exchange rate theories and models are considered the main weakness of the international macroeconomy.

Therefore, existing exchange rate models will not be able to take offsample forecasts for two main reasons. First, exchange rate theories and models fail to achieve out-of-sample proportions in previous research. Second, exchange rate models are based on macroeconomic fundamentals. Hence, to understand the impact of military operations on the exchange rate, we must go beyond traditional exchange rate forecasting theories and models.

Compared to exchange rate studies, there is not much literature on military tension studies. However, studies in this area are expanding rapidly due to growing concerns about global military tensions. Incidents of military tensions come in many forms, and terrorist motives can vary. In this regard, research articles in this field show diversity in terms of focus area. For example, a study by Landes, 1978 [14] is one of the first studies to evaluate anti- 
GÉNERO E INTERDISCIPLINARIDADE
$\mathrm{Vol}^{\circ} 02\left|\mathrm{n}^{\mathrm{o}} 01\right|$ ISSN: 2675-7451

https://www.periodicojs.com.br/index.php/gei/inde military tension policies in the literature. The author examines the installation of metal detectors at airports and the increase in penalties for hijacking in the United States. Lands (Ehrlich \& Becker, 1972 [15]) adapted the crime complicity model to hijacking and used the Ordinary Least Squares (OLS) to determine the impact of increased security measures at US airports. The author uses quarterly data on hijacking events in the United States between 1961 and 1976. His findings show that both increased punishment and security at airports have a deterrent effect on hijackings. Other similar studies by Cauley and Im (1988 [16] and Enders and Sandler, 1990 [17]) suggest that the installation of metal detectors at airports is likely to cause replacement or relocation. In other words, policies designed to reduce one type of terrorist attack are likely to increase other types of military operations.

In addition to studying military tensions, researchers are also interested in studying the effects of military tensions on the economy. Terrorist incidents impose economic costs on the target country in various ways. For example, a research study by Shahzad et al., 2016 [18], assessed the impact of military tensions on foreign direct investment (FDI) in Pakistan. The authors find that military tensions have an increasing impact on FDI. Another study by Aldor and Melnik, 2004 [19] examined the effects of military tensions on financial markets and the results of their study show that the intensity of Palestinian military operations has a permanent negative impact on the stock market.

Despite the increase in the number of studies examining the effect of military operations on some macroeconomic variables, the number of studies examining the effect of military operations on the exchange rate is limited. Therefore, in this study, we examine the effect of military operations on the exchange rate using the Turkish lira and the pound sterling. By examining the causal effects of military tensions, we want to contribute to the current literature and provide information to policymakers, business, and society. In the next section, we present the estimation method and data used to achieve the purpose of the study.

\section{METHODOLOGY}


GÊNERO E INTERDISCIPLINARIDADE

This research will study and reveal the research problem with a formalistic approach. In this research, the totality of recent opinions and events is considered. This research is qualitative and does not have a variable and a statistical population. The research method of this research is qualitative with an analytical and descriptive approach and is based on the study of library resources, audio and video archives and data collection. Qualitative research is exploratory (not positive) and in the proposed field is based on the study of written and content texts, therefore it has no variables and population and statistics.

\section{Findings}

The "Operation Spring of Peace", which began on October 9, 2019, is the third major Turkish military operation on Syrian soil since 2016, after Operation Euphrates Shield (2016-2017) and Olive Branch (2018). Although Turkish President Recep Tayyip Erdogan's decision to attack the Kurdish Democratic Union Party (PYD) in northeastern Syria has come as a surprise to some, it is in line with the logic of a regime fighting the Kurdistan Workers' Party (PKK). KK - Recognized as
$\mathrm{Vol}^{\circ} 02\left|\mathrm{n}^{\mathrm{o}} 01\right|$ ISSN: 2675-7451

https://www.periodicojs.com.br/index.php/gei/inde

"terrorist" not only by Turkey but also by the United States and the European Union - is one of its top security priorities.

What is new is the fight against $p$. It is not, but rather the strategic separation of Turkey from its two allies, the European Union and the United States. The secession began in 2016, when a failed military coup in Turkey prompted President Erdogan to strengthen ties with Moscow. Since then, he has become more authoritarian, using anti-Western rhetoric and pursuing foreign policies contrary to the interests of the Atlantic Alliance. Given the Trump administration's withdrawal from Syria, the Turkish military move could also be seen as an attempt to fill a power vacuum in the region and consolidate its influence there with its new ally, Russia.

Turkey is a longtime partner of the European Union. However, negotiations on the country's accession to the European Union have stalled after deviating from the constitutional and constitutional requirements of the European Union. In 2019, the European Parliament called on the Council of the European Union and the European Commission to suspend negotiations on Turkey's accession to the European 
GÉNERO E INTERDISCIPLINARIDADE
$\mathrm{Vol}^{\circ} 02\left|\mathrm{n}^{\mathrm{o}} 01\right|$ ISSN: 2675-7451

https://www.periodicojs.com.br/index.php/gei/inde
Union. Despite positive cooperation on immigration and the EU-Turkey agreement, which provides $€ 6$ billion for some 3.6 million Syrian refugees, Turkey's invasion of northeastern Syria could damage its EU membership prospects. Reach and create a new wave. Internally displaced persons and refugees, as well as security threats related to foreign ISIL / ISIL fighters present in Syria.

\section{FROM THE FAILED} MILITARY COUP TO THE SPRING OF PEACE OPERATION

The Turkish "Spring of Peace" military operation, which began on October 9, 2019 in northeastern Syria, is the result of internal and external dynamism created by the Syrian civil war (2011) and the failed military coup in Turkey (2016). Turkish President Recep Tayyip Erdogan's undemocratic methods and decisions, including the adoption of 18 amendments to the Constitution (2017), the merger of ministries and the accession of other institutions such as the Army Headquarters, the National Intelligence Agency and the National Security Council, directly to the President, in The establishment of the "Imperial Presidency" helped him. While these changes provoked strong criticism in the West, they were welcomed with understanding and support in Moscow. In July 2016, during a military coup, Russia expressed support for Erdogan, and at a Putin-Erdogan bilateral meeting in St. Petersburg, confirmed Turkey's first major operation in Syria, the Euphrates Shield, which lasted from August 2016 to March 2017. Earlier, Erdogan's plans for military intervention in Syria were opposed by the Obama administration and the Turkish military. Politically, the Euphrates shield paved the way for the Astana process, where Russia and Turkey sought to achieve a normal course in Syria. Iran later joined the initiative, and Iraq became an "observer" in October 2019.

In 2016, Turkey found itself caught between a powerful rival - Russia - in the Syrian territories west of the Euphrates and a non-model ally to its needs - the United States - east of the Euphrates. The Euphrates Shield allowed Turkey to clear the area west of the Euphrates River of both the Islamic State of Iraq and the Levant (ISIL / ISIL) and the People's Protection Units (YPG), mainly Kurdish groups that are a key 
GÊNERO E INTERDISCIPLINARIDADE
$\mathrm{Vol}^{\circ} 02\left|\mathrm{n}^{\mathrm{o}} 01\right|$ ISSN: 2675-7451

https://www.periodicojs.com.br/index.php/gei/inde component of the group. Syrian Democratic Forces Democratic Union Party (PYD, opposition to Bashar alAssad). Turkey considers the YPG affiliated with the Syrian Kurds of the Kurdistan Workers' Party (PKK), which it considers a "terrorist" organization. In addition, p. Is on the EU list of "individuals and entities subject to specific restrictive measures to combat military tensions" (Decision 2002/460 / EC) since 2002, as well as on the list of foreign terrorist organizations of the Ministry of Foreign Affairs. US State Department (FTOs). However, Western countries consider the PYD and the PKK to be two distinct legal entities, although historically and operationally related. Despite the fact that the PYD fought against ISIL / ISIL and was therefore an ally of the West against military tensions, US President Donald Trump said in October 2019 that P. It is "probably" a "bigger terrorist threat" than the Islamic State armed groups.

When Turkey carried out the second major military operation in Syria, the Olive Branch, in the Afrin canton of Syrian Kurdistan between January and March 2018, it became clear that ISIL / ISIL forces had been significantly weakened. The US military withdrawal from Syria, announced by Trump in December 2018 after he claimed that the "Islamic State" had failed, created a new opportunity not only for Turkey but also for its regional allies, Russia and Iran. Given the evolution of the conflict, Operation October 2019 may be understood as a "war within a war." It was more a step towards strategically separating Ankara from its Western allies, thanks to the Trump administration's inappropriate decisions and the EU's weak stance on Syria, where, with the exception of British and French troops, there are no EU troops on the ground. Chatham House researchers speak of a "lack of a coherent strategic vision" that has led to "Western marginalization in Syria."

\section{EU-TURKEY RELATIONS}

Turkey has been a member of NATO since 1951 and is a longtime partner of the European Union. The Association Agreement between the European Economic Community (EEC) and Turkey in 1963 was a temporary step towards the country's accession to the European Union, which was requested in 1959. EU candidate status in 1999. In December 2004, the Council of Europe 
GÉNERO E INTERDISCIPLINARIDADE
$\mathrm{Vol}^{\circ} 02\left|\mathrm{n}^{\mathrm{o}} 01\right|$ ISSN: 2675-7451

https://www.periodicojs.com.br/index.php/gei/inde decided that Turkey had sufficiently met the criteria for EU membership and that it was possible to start accession negotiations with it. In 2008, the council approved a revised partnership for accession to Turkey. Turkey has been a member of the EU Civil Protection Mechanism since 2015 and has agreed to join the European Solidarity Corps.

In 2016, under an EU statement, Turkey and Turkey both agreed on EU facilities for refugees in Turkey. The facility manages a total of $€ 6$ billion in budget: $€ 3$ billion for 2016-2017 fully contracted and over $€ 2$ billion paid, however, the balance remains on the implementation of facility projects until mid-2021 In 2018, the Council of Europe agreed to finance the second part of the facility, with resources from the EU budget ( $€ 2$ billion) and member states ( $€$ 1 billion). Importantly, the EU-Turkey statement regarding the facility stated that "all illegal immigrants who cross the Turkish-Greek islands from 20 March 2016 will be returned to Turkey." The bilateral agreement between Greece and Turkey (2016) provides for the mutual presence of police forces in refugee camps in Greece and Turkey, respectively.
At the Varna Summit (2018), the EU-Turkey talks were once again focused on cooperation in the field of migration, combating military tensions and Turkish intervention in Syria. Despite EU concerns about the rule of law, freedom of the press and parliamentary democracy, the EUTurkey high-level political dialogue continued with a strong focus on foreign affairs and security, mainly in relation to Syria and Iraq. However, as stated in the 2019 Commission report on Turkey, "there is a slow pace towards the concrete implementation of the agreed joint measures". The report also notes that "the situation in southeastern Turkey continues to be challenged in the fight against military tensions. The government continues security operations against the backdrop of repeated acts of violence by the Kurdistan Workers' Party (PKK)." The report also notes that "while the government has a legal right to fight military tensions, it also has a responsibility to ensure that it is carried out", which is still on the EU list of individuals, groups and institutions involved in terrorist acts. It is also responsible for human rights and fundamental freedoms in accordance 
GÉNERO E INTERDISCIPLINARIDADE

with the rule of law. Anti-terror measures must be proportionate.

\section{EU REACTIONS TO} OPERATION PEACE SPRING

The gap between the EU and Turkey will deepen as a result of the peace spring, which Turkey sees as a tool to counter the terrorist threat.

$\mathrm{K}$ knows the situation of Syrian refugees inside Turkey. EU High Representative / Vice-President (HR / VP) Federica Mogherini told a plenary session of parliament on October 9 that "[Turkish] military action undermines the security of the coalition's local partners, the Kurdish forces, and prolongs instability." In northeastern Syria, it provides the right ground for the resurgence of ISIS. "We hope that the Turkish invasion will not delay the first meeting of the Constitutional Committee," he said. However, we can not rule out this possibility. The 150member Syrian Constitutional Committee, which is divided equally between the Syrian government, the opposition and Syrian civil society, was established in September 2019. The delegation has the task of amending the Syrian constitution and launching a
$\mathrm{Vol}^{\circ} 02 \mid \mathrm{n}^{\circ} 01$ | ISSN: 2675-7451

https://www.periodicojs.com.br/index.php/gei/inde broader political process before the 2021 presidential election.

At the Council of Europe meeting on 17-18 October. EU leaders endorsed the October 14th Council deliberations on relations with Turkey, condemned Turkey's unilateral military action, and called on Turkey to withdraw its forces and abide by international humanitarian law. They also stressed that the Turkish operation "causes unacceptable human suffering, weakens the fight against ISIS and poses a serious threat to European security", and stated that, "recalling the decision taken by some member states To immediately suspend arms exports to Turkey with authorization, member states are committed to strong national positions on arms export policy to Turkey in accordance with the provisions of Common Position 2008/944 / CFSP on arms control, EU leaders said. Syria's unity, sovereignty and territorial integrity are committed. These can only be reassured through a real political transition in accordance with UN Security Council Resolution 2254. Finally, they called on Turkey to respect the 120-hour ceasefire agreement negotiated by US Vice President Mike Pence on October 17, and said that Britain, France and Germany would 
GÉNERO E INTERDISCIPLINARIDADE

form a tripartite dialogue with Ankara within a few weeks. They will meet. "

European Parliament President David Sassoli described the Turkish attack as a "war action". "We must do everything we can to stop this aggression and start an initiative that can be suppressed in NATO and presented to the UN Security Council," he said in a speech to the Council of Europe on October 17. "In this regard, the European Parliament reiterates its call for the suspension of accession talks with Turkey," he said, adding that he was speaking with one voice when trying to make peace in multilateral forums., Parliament passed a resolution on Turkish military operations in northeastern Syria and its aftermath, in which it strongly condemned Turkish intervention and called for the withdrawal of all troops from Syrian territory, a threat to the Islamic State. And rejects Turkey's plan for a "safe zone" and calls for a UN-led security zone.

\section{ANALYSIS OF FALLING VALUE OF THE LIRA}

One of the victims of the Turkish military strike on Syria is recovering
$\mathrm{Vol}^{\circ} 02 \mid \mathrm{n}^{\circ} 01$ | ISSN: 2675-7451

https://www.periodicojs.com.br/index.php/gei/inde

from the recession after US congressional leaders threatened sanctions that could reach the lira and increase Turkey's distrust of Western allies.

The Turkish currency - which was in crisis a year ago due to part of US sanctions and tariffs - ordered US forces to attack Kurdish forces there at their weakest level in nearly four months after US troops left northeastern Syria and Ankara. Receipt.

In recent months, the lira has been stable and inflation has fallen, indicating that the $\$ 766$ billion economy in Turkey, the largest economy in the Middle East, has experienced its worst recession in nearly two decades.

The central bank has cut interest rates to begin lending in July. But as of Thursday, market expectations tmsnrt. rs / 2HFCPtg was restrained to further facilitate policies as investors worried that the outcome of these conflicts could delay recovery.

If the Turkish military is caught for a long time, these risks include a larger deficit and the cost of borrowing and reducing tourism.

But the biggest threat - and the threat that investors say Turkish assets are priceless - is a new determination 
GÊNERO E INTERDISCIPLINARIDADE

among senior US Republicans to punish Turkey for attacking Syria's Kurds, Washington's main allies in the fight against the Islamic State. .

Republican Sen. Lindsey Graham, who is often a staunch supporter of Donald Trump, joined a Democrat on Wednesday to unveil a framework for sanctions, and praised the president's decision to withdraw US troops.

Graham's proposal targets the assets of Erdogan and other high-ranking officials, imposes visa restrictions, and imposes sanctions on anyone who conducts military deals with Turkey or supports energy production.

Turkey could face broader sanctions under Graham's plan to buy Russian S-400 missile defenses this year, despite strong opposition from Washington.

The lira, which lost about 30 percent of its value last year, has fallen more than 3 percent in volatile trading this week as it rose to $\$ 5.90$.

Traders said it was unclear how much it could have fallen if state banks had not acted to sell the dollar and eased the pressure earlier in the week.

In Turkey, which relies on foreign investment, the currency largely determines prices, which in turn
$\mathrm{Vol}^{\circ} 02 \mid \mathrm{n}^{\circ} 01$ | ISSN: 2675-7451

https://www.periodicojs.com.br/index.php/gei/inde

determines monetary policy. Investors said any lira above 6 could indicate a possible expectation of sanctions.

A senior Turkish banker, speaking on condition of anonymity, said the weakness so far reflected the immediate geopolitics of the attack, not sanctions, which are "the biggest threat".

"Relations with the United States are an important concern that we cannot yet anticipate," he said, adding that the concerns would continue, at least until Erdogan's scheduled talks with Trump in the United States on November 13.

Turkish Finance Minister Barat Albayrak may attend the annual meetings of the World Bank and International Monetary Fund in Washington next week.

While Albayrak has painted a picture of Turkey's economic resilience in recent weeks, bonds and stocks have fallen this week, including a drop of more than 5 percent in Turkey's major stock index.

Money Market Traders TRYAM3L3MF3M = now forecast the central bank to cut rates to $15 \%$ by the end of the year, from $16.5 \%$ now, instead of the $13.5 \%$ they forecast at the end of last week. Four traders said they are 
GÉNERO E INTERDISCIPLINARIDADE

expected to drop 50 to 75 points later this month.

Indeed, there is a direct link between rising tensions in Idlib, Syria, and increasing pressure on the Turkish economy, including its monetary value. As this tension and crisis escalates into a wider war, pressures on Turkey will increase, especially as the issue of security, which is critical to the tourism industry, is overshadowed. And as we know, the Turkish tourism industry is the first lucrative industry in this country. An industry that has been a factor in Turkey's economic growth over the past two decades. Another important issue is the growing dependence of the Turkish economy on regional and neighborly relations; In the field of food industry, agriculture and other fields, so that the amount of economic exchanges between Turkey and Russia has increased, and in the Syrian crisis, we see that Turkey is on one side of the story and Russia on the other. And with the escalation of tensions in the Syrian crisis, we have seen the closure of Russia's borders on Turkish food and agricultural products, and this has created a serious crisis among Turkish farmers, which is one of the main markets for Turkish sales, and now there is a fear of losing it. . Another
$\mathrm{Vol}^{\circ} 02 \mid \mathrm{n}^{\circ} 01$ | ISSN: 2675-7451

https://www.periodicojs.com.br/index.php/gei/inde issue is that the largest number of Turkish tourists each year are Russian citizens, which is another part of the Turkish government's revenue. Given this issue, the current situation makes the Turkish economy more fragile and, as we see, the lira depreciates against the dollar.

\section{CONCLUSION}

The main purpose of this study is to investigate the impact of terrorist attacks on the exchange rate in Turkey. Mainly, in this study, we seek to increase the scope of research on the impact of a terrorist attack on the currency. In fact, for the author, this study is unique in identifying the impact of a terrorist attack on the exchange rate between the Turkish lira. In addition, the purpose of this article is to provide input for policymakers and business in formulating policy interventions and business strategies, respectively. In fact, the present study provides a valuable policy and business strategy input for policy makers and businesses, respectively. The rise of emerging markets is largely due to indicators such as the possibility of a Sino-US trade deal and provocative measures, but observers 
GÉNERO E INTERDISCIPLINARIDADE

about Turkey are concerned about the imposition of international sanctions on the country over military operations in Turkey. And the most important point of the research is that, although the average impact of terrorist attacks on the Turkish lira is negative, but in some cases we see the exchange rate remain stable or prices rise. This could be due to the location in the city where the terrorist attack took place and which has been covered by the media.

\section{References}

Jost J. Institute for Economics \& Peace: Global Terrorism Index 2015. SIRIUSZeitschrift für Strategische Analysen. 2017 Feb 21;1(1):91-2.

Abadie A, Gardeazabal J. The economic costs of conflict: A case study of the Basque Country. American economic review. 2003 Mar;93(1):113-32.

Enders W, Sandler T. Terrorism and foreign direct investment in Spain and Greece. Kyklos. 1996 Aug;49(3):33152.

Chen AH, Siems TF. The effects of terrorism on global capital markets. European journal of political economy. 2004 Jun 1;20(2):349-66.
$\mathrm{Vol}^{\circ} 02\left|\mathrm{n}^{\mathrm{o}} 01\right|$ ISSN: 2675-7451

https://www.periodicojs.com.br/index.php/gei/inde
Pshisva R, Suarez GA. 'Captive markets': the impact of kidnappings on corporate investment in Colombia. 2017

Sakarya S, Soyer N. Cultural differences in online shopping behavior: Turkey and the United Kingdom. " International Journal of Electronic Commerce Studies". 2014 May 22;4(2):213-38.

Meese RA, Rogoff K. Empirical exchange rate models of the seventies: Do they fit out of sample?. Journal of international economics. 1983 Feb 1;14(1-2):3-24.

Mussa M. Macroeconomic interdependence and the exchange rate regime. International economic policy: Theory and evidence. 1979:160-99.

Meese RA, Rose AK. An empirical assessment of non-linearities in models of exchange rate determination. The Review of Economic Studies. 1991 May 1;58(3):603-19.

Engel C. Can the Markov switching model forecast exchange rates?. Journal of international economics. 1994 Feb 1;36(1-2):151-65.

Taylor MP. The economics of exchange rates. Journal of Economic literature. 1995 Mar 1;33(1):13-47.

Bacchetta P, Van Wincoop E. Can information heterogeneity explain the exchange rate determination puzzle? 
American Economic Review. 2006 Jun;96(3):552-76.

Landes WM. An economic study of US aircraft hijacking, 1961-1976. the Journal of Law and Economics. 1978 Apr 1;21(1):1-31.

Ehrlich I, Becker GS. Market insurance, self-insurance, and self-protection. Journal of political Economy. $1972 \mathrm{Jul}$ 1;80(4):623-48.

Cauley J, Im EI. Intervention policy analysis of skyjackings and other terrorist incidents. The American Economic Review. 1988 May $1 ; 78(2): 27-31$.

Enders W, Sandler T, Cauley J. Assessing the impact of terroristthwarting policies: An intervention time series approach. Defence and Peace Economics. 1990 Dec 1;2(1):1-8.

Shahzad SJ, Zakaria M, Rehman MU, Ahmed T, Fida BA. Relationship between FDI, terrorism and economic growth in Pakistan: Pre and post 9/11 analysis. Social Indicators Research. 2016 May 1;127(1):179-94.

Eldor R, Melnick R. Financial markets and terrorism. European Journal of Political Economy. 2004 Jun 1;20(2):367-86.

Pesaran MH, Shin Y, Smith RJ. Bounds testing approaches to the analysis of level relationships. Journal of applied econometrics. 2001 May;16(3):289-326. 